\title{
Carbon Footprint Analysis and Reductive Project Evaluation of Iron-making Enterprise Based on LCA
}

\author{
Kaiming Liang ${ }^{1, a}$, Yun Zhang ${ }^{1, b}$, Jinhua $\mathrm{Li}^{1, \mathrm{c}}$, Chenchen Zhao ${ }^{1, \mathrm{~d}}$ \\ ${ }^{1}$ Key Laboratory of Industrial Ecology and Environmental Engineering (MOE), School of \\ Environmental Science and Technology, Dalian University of Technology, 2 Linggong Road, Dalian \\ 116024, China \\ akennightbrother@126.com, 'bhangyun@dlut.edu.cn, ${ }^{\mathrm{a}}$ lijinhua@mail.dlut.edu.cn, ${ }^{\mathrm{d}} \mathrm{zhaochenchen0}$ \\ 704@126.com
}

Keywords: Iron-making enterprise, Life cycle assessment, Global warming potential, Carbon footprint, Carbon reduce emission project.

\begin{abstract}
There is a great significance to analyze carbon footprint of iron-making process and to reduce its environmental impact since iron-making enterprises generate massive greenhouse gas. In this paper, the environmental impact type referred to Global Warming Potential was applied to analyze the carbon footprint and environmental impact for each production process in iron-making enterprise based on life cycle assessment. Blast furnace process has the largest contribution in carbon footprint, followed by sintering process. According to the analysis, seven carbon emission reduction projects were carried out in series. Afterwards, the LCA was used to evaluate the environmental benefits by seven projects.
\end{abstract}

\section{Introduction}

Climate warming has become the focus of attention of the society caused by greenhouse gases. As a carbon emitter, annual emissions of $\mathrm{CO}_{2}$ reaches more than 50 million ton in Chinese integrated iron and steel enterprise, accounting for about 9.2\% of nation [1], while the $\mathrm{CO}_{2}$ emissions in iron-making enterprises account for integrated iron and steel enterprises in the total amount of emissions $80 \%$ [2]. In order to achieve the goal that the amount of $\mathrm{CO}_{2}$ drops $40-45 \%$ from 2005 to 2020, analysis of carbon footprint and carbon emission reduction of iron-making enterprises is very important.

Life cycle assessment (LCA) is an evaluation method to measure the environmental impact on various research objects, ranging from raw material acquisition, product processing, packaging, and usage to waste disposal and thus includes a quantitative evaluation of the entire life cycle. The method can be used for evaluating environmental effect of different industries [3-5]. LCA is widely used in the steel industry [6], such as establishing inventory of iron and steel industry [7], analyzing environmental effect of iron and steel industry [8-9], evaluating environmental effect of different technologies of steelmaking slag treatment [10], etc. However, it's lack of life cycle assessment method combing iron-making enterprise footprint to evaluate the carbon emission reduction schemes.

In this paper, an iron-making enterprise in China was selected and LCA was applied to evaluate iron-making enterprise footprint. First, LCA was used to evaluate footprint impact of the enterprise by analyzing different production stages. Based on evaluation results, we proposed and screened corresponding carbon reduction schemes. This study can provide support for managers to make decisions, and provide technical guidance for carbon emission reduction of iron-making enterprises.

\section{Method}

According to the definition of the ISO14040 standard, life cycle assessment framework consists of four parts: goal and scope definition, inventory analysis, impact assessment and interpretation of results. 
Goal and Scope Definition. The purpose of the paper includes the following:

1. Using the LCA method to analyze the iron-making enterprise production process and its carbon footprint environmental impact and propose carbon reduction schemes accordingly.

2. Applying the LCA method towards 7 carbon reduction schemes to screen environmentally feasible carbon reduction schemes, and carry out the quantitative assessment of its environmental benefits.

The scope of this research included sintering and blast furnace smelting, as well as auxiliary processes, such as quick lime smelting, electricity production, natural gas extraction, coke smelting, and so on.

In this paper, the function of the unit is $2712.8 \mathrm{t}$ pig iron.

Inventory Analysis. The data used in the paper for sintering and blast furnace smelting, and carbon reduction schemes are based on the iron-making enterprise, which is located in a large steel industrial park in Liaoning, China. The gas in the iron-making enterprise is provided by the industrial park, which is a mixture of generator gas, blast furnace gas, converter gas, and natural gas at a ratio of 39:15:5:1. The discharge of CO2 is calculated using a literature index [11]. Water supply, electricity production and other auxiliary unit data are from the GaBi professional database and the Ecoinvent Database. The life cycle data list is shown in table 1.

Table 1 Resource, energy consumption and emission inventory of the iron-making enterprise

\begin{tabular}{cccccc}
\hline Material & Unit & Quantity & Material & Unit & Quantity \\
\hline Input & & & & & \\
Iron ore & $\mathrm{t}$ & 3089 & Coal & $\mathrm{t}$ & 703.8 \\
Nickel ore & $\mathrm{t}$ & 270 & Electricity & Kwh & 480506.4 \\
Pellet feed & $\mathrm{t}$ & 318.8 & Generator gas & $\mathrm{m}^{3}$ & 1255451.997 \\
Lump ore & $\mathrm{t}$ & 232 & Blast furnace gas & $\mathrm{m}^{3}$ & 482866.14 \\
Quick lime & $\mathrm{t}$ & 435.89 & Converter gas & $\mathrm{m}^{3}$ & 160955.38 \\
Limestone & $\mathrm{t}$ & 276 & Natural gas & $\mathrm{m}^{3}$ & 32191.076 \\
Magnesite & $\mathrm{t}$ & 72 & Pyrolysis gas & $\mathrm{t}$ & 123 \\
Coke & $\mathrm{t}$ & 1202.16 & Water & $\mathrm{t}$ & 207364 \\
Anthracite & $\mathrm{t}$ & 209.5 & Compressed air & $\mathrm{m}^{3}$ & 34171 \\
Nitrogen & $\mathrm{m}^{3}$ & 62148 & & & \\
Output & & & & $\mathrm{t}$ & \\
Iron & $\mathrm{t}$ & 2712.817 & Nitrogen dioxide & $\mathrm{t}$ & \\
Carbon dioxide & $\mathrm{t}$ & 1557937.02 & Blast furnace slag & $\mathrm{t}$ & 1039.872 \\
Dust & $\mathrm{t}$ & 202.045 & Waste water & $\mathrm{t}$ & 207364 \\
Sulfur dioxide & $\mathrm{t}$ & 21.59 & Blast furnace gas & $\mathrm{m}^{3}$ & 3832995 \\
\hline
\end{tabular}

\section{Results and Discussion}

Life Cycle Assessment of the Iron-making Process. In the paper, Global Warming Potential (GWP) was chosen as the index of environmental impact of this study, and GaBi5.0 software was used to analyze the LCA of the iron-making enterprise The carbon footprint environmental impact analysis results of the iron-making enterprise was shown in fig. 2, where " 1 " representatives generator gas production, "2" representatives of electricity production, “3" representatives natural gas extraction procedure, "4" representatives of the limestone mining, "5" representatives of pyrolysis gas production, "6" representatives of lime smelting, "7" representatives of tap water production, "8" representatives of coke smelting, "9" representatives of sintering, " 10 " representatives of blast furnace smelting. Carbon footprint environmental impact of the iron-making enterprise in each stage was shown in fig. 2 . The blast furnace smelting is the largest contribution, the second is the sintering. The third is the electricity production because large amount of $\mathrm{CO}_{2}$ is generated by coal burning through fired power plants in northern China. The value of GWP of the blast furnace smelting and the sintering is much higher than other process of iron-making enterprise, because of more fuel gas 
expended and more $\mathrm{CO}_{2}$ production.

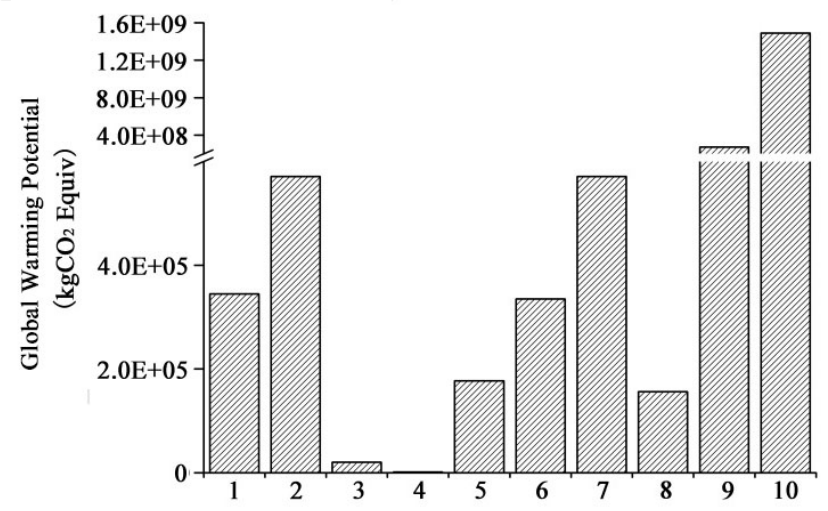

Fig. 2. GWP value comparison of each process of the iron-making enterprise

Analysis of Carbon Emission Reduction Schemes. To achieve the goal of carbon emission reduction, seven schemes were produced including 4 aspects: raw materials substitution, technology renovation, equipment control updates and process optimization. $\mathrm{CO}_{2}$ generated from gas consumption in the blast furnace smelting and sintering process and electricity consumption in the iron-making process has the greatest environmental impact. Therefore, the schemes in the iron-making enterprise should aim at lowering energy consumption of the iron-making process and the schemes are shown in table 2.

Table 2 Carbon reduction projects summary

\begin{tabular}{|c|c|c|c|}
\hline $\begin{array}{l}\text { Scheme } \\
\text { Number }\end{array}$ & Scheme & Description & Assumptions \\
\hline S1 & $\begin{array}{l}\text { Improving the } \\
\text { grade of iron } \\
\text { ore }\end{array}$ & $\begin{array}{l}\text { Improving the grade of iron ore, reducing the coke rate, } \\
\text { increasing the amount of iron according to } 1: 1.74: 2.39 \text {. } \\
\text { Original iron ore grade of } 56 \% \text { went up to } 65 \% \text {. }\end{array}$ & $\begin{array}{l}\text { Reducing the } \\
\text { coke ratio by } \\
15.66 \% \text {, } \\
\text { increasing the } \\
\text { output of iron by } \\
21.51 \%\end{array}$ \\
\hline S2 & $\begin{array}{l}\text { Establishing } \\
\text { the system of } \\
\text { stove } \\
\text { automatic } \\
\text { combustion }\end{array}$ & $\begin{array}{l}\text { Establishing the system of stove automatic combustion, } \\
\text { replacing the gas burner valve, inputting the program of the } \\
\text { automatic combustion system. }\end{array}$ & $\begin{array}{l}\text { Decreasing gas } \\
\text { by } 240000 \mathrm{~m}^{3}\end{array}$ \\
\hline S3 & $\begin{array}{l}\text { Establishing a } \\
\text { heat recovery } \\
\text { boiler }\end{array}$ & $\begin{array}{l}\text { Establishing a dual-temperature-stage heat recovery boiler, } \\
\text { allowing wasted heat to transform into steam to supply the } \\
\text { industrial park. }\end{array}$ & $\begin{array}{l}\text { Decreasing } \\
\text { standard coal by } \\
8.32 \mathrm{t}\end{array}$ \\
\hline S4 & $\begin{array}{l}\text { Coal injection } \\
\text { system into } \\
\text { operation }\end{array}$ & $\begin{array}{l}\text { By further improving the ratio of coal injection and the } \\
\text { reducing coke ratio, the ratio of coal injection increased from } \\
\text { an average of } 100 \mathrm{~kg} / \mathrm{t} \text { to } 160 \mathrm{~kg} / \mathrm{t} \text { and the rate of coke } \\
\text { decreased from an average of } 410 \mathrm{~kg} / \mathrm{t} \text { to } 314 \mathrm{~kg} / \mathrm{t} \text {. }\end{array}$ & $\begin{array}{l}\text { Reducing coke } \\
\text { 288t, increasing } \\
\text { the pulverized } \\
\text { coal 180t }\end{array}$ \\
\hline S5 & $\begin{array}{l}\text { Ignition } \\
\text { sintering } \\
\text { retrofitting }\end{array}$ & $\begin{array}{l}\text { Retrofitting the existing gas pipeline DN400 instead of } \\
\text { DN600. }\end{array}$ & $\begin{array}{l}\text { Decreasing gas } \\
\text { by } 75000 \mathrm{~m}^{3}\end{array}$ \\
\hline S6 & $\begin{array}{l}\text { Waste heat } \\
\text { recovery of } \\
\text { water slag of } \\
\text { Blast furnace }\end{array}$ & $\begin{array}{l}\text { Waste heat recovery by blast furnace slag flushing water to } \\
\text { save energy. }\end{array}$ & $\begin{array}{l}\text { Decreasing } \\
\text { standard coal } \\
\text { by } 4.2 \mathrm{t}\end{array}$ \\
\hline S7 & $\begin{array}{l}\text { Dust } \\
\text { transformation }\end{array}$ & $\begin{array}{l}\text { The pellet dust is transported to the disabled bentonite } \\
\text { chamber, the original open bentonite chamber reconstruction } \\
\text { with warehouse item precipitator as closed dust ash bin, to } \\
\text { reduce the drying temperature dryer. }\end{array}$ & $\begin{array}{l}\text { Decreasing gas } \\
\text { by } 60000 \mathrm{~m}^{3}\end{array}$ \\
\hline
\end{tabular}


This study investigates the iron-making enterprise and analyzes GWP value of 7 carbon footprint reduction schemes. The results are shown in fig. 3 . T represents no taking scheme.

The carbon reduction benefits of the 7 schemes are shown in fig. 3, which shows that $\mathrm{S} 1$ is the most promising scheme, followed by $\mathrm{S} 2<\mathrm{S} 3<\mathrm{S} 6<\mathrm{S} 5<\mathrm{S} 7<\mathrm{S} 4$.

Result shows that "improving the grade of iron ore" can improve production efficiency to reduce carbon emission." Coal injection system into operation” decreases little GWP value. Although the scheme reduces coke in the production input process, pulverized coal increased. Other schemes have obvious environmental benefits. 7 carbon reduction schemes in the implementation, the GWP value reduced from original $1.76 \mathrm{E}+9\left(\mathrm{kgCO}_{2}\right.$-Equiv) to $1.48 \mathrm{E}+9\left(\mathrm{kgCO}_{2}\right.$-Equiv), and carbon footprint effect is reduced.

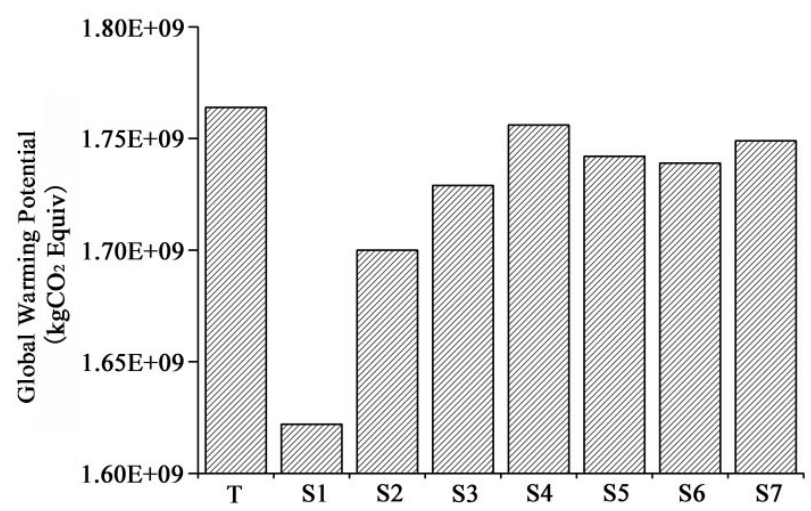

Fig. 3 The environmental impact comparison between each carbon reduction project and non-carbon reduction project of the iron-making enterprise

\section{Conclusion}

In this research, LCA was used to analyze carbon footprint environmental impact of each stage in the case iron-making enterprise. We concluded that the largest contribution to environmental impact types GWP was blast furnace smelting, followed by sintering, because that more fuel gas was consumption in blast furnace smelting and sintering.

On the other hand, LCA was used to evaluate 7 carbon reduction schemes based on reducing energy consumption in the iron-making enterprise. The effect of "improving the grade of iron ore" is best and "Coal injection system into operation" is not better than other schemes.

\section{Acknowledgments}

This study was supported by the Public Research Fund on Scientific Undertakings in Liaoning Province, China (2014003021) and the Major Science and Technology Program for Water Pollution Control and Treatment (2012ZX07202-001).

Corresponding author: Zhang Yun.

Email: zhangyun@dlut.edu.cn

\section{References}

[1] X. Liu, H. Bai, L.H. Zhao, N. Li, H.F. Li, Analysis of $\mathrm{CO}_{2}$ emissions of iron and steel making process, Energy for Metallurgical Industry. 1 (2012) 5-9.

[2] Q. Zhang, F. M. Shen, Cost and $\mathrm{CO}_{2}$ emission reducing optimization analysis of iron-making system in iron and steel industry. 2014.

[3] Q.Q. Ji, Q.H. Zhang, J.Q. Xiong, R. Chen, X.C. Wang, Application of LCA on cost-effectiveness of urban wastewater reclamation, Chinese Journal of Environmental Engineering. 3 (2010) 517-520. 
[4] X.Y. Liu, X.F. Xia, S.X. Zhou, B.D. Xi, Y. Zhang, Life cycle of environmental impact assessment of new and renewable laser supplies, Chinese Journal of Environmental Engineering. 10 (2011) 2396-2400.

[5] W.H. Piao, Y. Chen, S.S. Zhang, X.N. Xu, Cleaner production audit for a cement enterprise based on LCA, Acta Scientiae Circumstantiae. 32 (2012) 1785-1792.

[6] H.C. Xu, C. X. Zhang, Cost and $\mathrm{CO}_{2}$ emission reducing optimization analysis of iron-making system in iron and steel industry, China Metallurgy. 10 (2007) 33-36.

[7] O. Mirgaux, D. Ablitzer, A.M. Iosif, How physical modelling can improve life cycle inventory accuracy and allow predictive LCA: an application to the steel industry, Revue De Metallurgie-Cahiers D Informations Techniques. 106 (2009) 579-584.

[8] D. Burchart-Korol, Life cycle assessment of steel production in Poland: a case study, Journal of Cleaner Production. 54 (2013) 235-243.

[9] Y.H. Liu, T.Liu, S.H. Guo, Environmental evaluation of steel products improvement form LCA perspective, Environmental Engineering. 2 (2013) 437-439.

[10] B. Chen, J.X. Yang, Z.Y. Ouyang, Life cycle assessment of internal recycling options of steel slag in Chinese iron and steel industry, China Population, Resources and Environmental. 10 (2010) 30-34.

[11] H.M. Zhou, Z.R. Nie, T.Y. Zuo, Assessment on $\mathrm{CO}_{2}$ life cycle inventory in iron and steel process, Guangzhou Environmental Sciences. 1 (2002) 21-24. 